\begin{tabular}{c} 
Politik Indonesia: Indonesian Political Science Review 1 (2) (2016) 212-230 \\
Politik Indonesia \\
Indonesian Political Science Review \\
http://journal.unnes.ac.id/nju/index.php/JPI \\
\hline \begin{tabular}{c} 
Indonesia \\
\hline
\end{tabular}
\end{tabular}

\title{
Pemilihan Kepala Daerah (Pilkada) dan Tantangan Demokrasi Lokal di Indonesia
}

\author{
Suyatno ${ }^{1,2 \bowtie}$ \\ ${ }^{1}$ Universitas Kanjuruhan, Malang, Indonesia \\ ${ }^{2}$ Universitas Airlangga, Surabaya, Indonesia
}

\section{Info Artikel}

Sejarah Artikel:

Diterima 12 Juni 2016

Disetujui 15 Juni 2016

Dipublikasi 15 Juli 2016

Keywords:

Pilkada; Participation;

Responsiveness; Local

Democracy

\begin{abstract}
Abstrak
Pilkada langsung pada akhirnya menggantikan pilkada tidak langsung didasari oleh semangat pemberdayaan masyarakat dalam berpartisipasi memilih kepala daerah secara lebih demokratis. Selain partisipasi terdapat unsur penting lainnya yang bisa menggambarkan berlangsungnya proses demokrasi lokal, yaitu responsivitas. Dua unsur tersebut dapat menentukan proses pilkada secara lebih substanstif daripada sekedar prosedur demokrasi lokal. Tulisan ini menggunakan metodologi kualitatif untuk menganalisa data partisipasi dan responsivitas pilkada sebagai variabel penting dalam demokrasi lokal. Partisipasi masyarakat dalam pilkada memang tidak setinggi partisipasi dalam pemilu di masa Orde Baru. Namun begitu partisipasinya bersifat substantif karena disertai penilaian terhadap kadar responsivitas pemimpin lokal. Petahana yang sukses menjalankan responsivitas lokal akan mendapatkan sukses lanjutan dalam wujud kemenangan pilkada berikutnya. Sebaliknya, petahana yang gagal dalam pelaksanaan responsivitas akan memperoleh kekalahan. Kemenangan dan kekalahan petahana dalam pilkada dapat dinyatakan bahwa keterkaitan partisipasi dan responsivitas menjadi amat penting dalam proses demokrasi lokal secara menyeluruh.
\end{abstract}

\section{Abstract}

Direct local leader elections (Pilkada) had replaced indirect local elections. It based on the spirit of people empowerment to participate choosing local leaders more democratic. Responsiveness is an important element besides participation which represent local democracy. These two variables will decide the local elections that can enhance the quality of local democracy. This paper uses qualitative methodology to analyze the data of participation and responsiveness of Pilkada as an important variables in local democracy. People participation in Pilkada is not as high as the participation in New Order elections. Their participation are more substantive because accompanied assessment of the level of responsiveness of a local leader. Incumbent successful running of local responsiveness will get continued success as the next local elections victory. In contrast, incumbent who failed in the implementation of responsiveness will obtain defeat. Victory and defeat incumbent in the election can be stated that the relevance of participation and responsiveness become very important in the local democratic process as a whole.

(C) 2016 Universitas Negeri Semarar

\footnotetext{
Alamat korespondensi:

Jl. Sudancho Supriyadi No.48 Malang 65148 Indonesia.

Jl. Airlangga 4-6, Surabaya 60286 Indonesia.

Email: yatno.ladiqi@gmail.com
} 


\section{Pendahuluan}

Pemilihan kepala daerah (pilkada) di Indonesia merupakan amanah langsung dari gerakan reformasi tahun 1998. Menimbang perlunya partisipasi yang kuat dari masyarakat untuk ikut terlibat langsung dalam pemilihan pemimpinnya, maka pemilihan kepala daerah menjadi momentum demokrasi yang paling penting dalam kehidupan berbangsa dan bernegara Indonesia. Sebagai wujud implementasi demokrasi, pilkada dimaksudkan tidak saja untuk memenuhi hasrat mengganti mekanisme lama pemilihan pemimpin dan wakil rakyat gaya otoriterisme, tetapi juga secara filosofis ingin menggapai pelaksanaan nilai-nilai demokrasi yang berkelanjutan, yaitu mengembangkan partisipasi dan responsivitas serta akuntabilitas secara menyeluruh.

Pada masa Orde Baru praktis implementasi otoriterisme lebih dominan untuk memilih kepala daerah di wilayah propinsi maupun kabupaten/kotamadya. Polapola top down dan patrimonial begitu mendominasi politik Indonesia, sehingga sangat wajar tuntutan reformasi yang paling esensial adalah mengganti praktek-praktek otoriterisme dengan mekanisme yang lebih demokratis, yaitu mekanisme pilkada. Hal ini sesuai dengan UUD 1945, Pasal 18 ayat (4) yang menyebutkan bahwa Gubernur, Bupati, dan Walikota masing-masing sebagai kepala pemerintahan daerah provinsi, kabupaten, dan kota dipilih secara demokratis.
Pada perjalanannya mekanisme pilkada mengalami perubahan dari pemilihan tidak langsung menjadi pemilihan langsung. Dinamika ini dilatar belakangi oleh berbagai alasan seperti 'perselingkuhan' wakil rakyat (DPRD) dengan calon Bupati/ Walikota/ Gubernur yang berimbas kepada korupsi politik dan akuntabilitas yang buram karena persekongkolan elit politik meniadakan transparansi tetapi justru menyemarakkan politik uang. Hal ini dimungkinkan karena DPRD lah yang memilih kepala daerah. Alasan tersebut menjadi puncak ketidak puasan terhadap pelaksanaan pilkada tidak langsung. Dengan begitu terjadi perubahan dari UU No. 22/1999 digantikan dengan UU No. 32/2004 yang mengatur pilkada secara langsung.

Tulisan ini hendak membahas proses pilkada sebagai wujud implementasi demokrasi lokal yang sarat dengan gambaran betapa partisipasi langsung masyarakat menjadi tolok ukur nyata demokrasi. Namun begitu seringkali sisi tanggung jawab pemimpin daerah yang terpilih kurang begitu disoroti sehingga seolah-olah setelah pilkada, proses demokrasi sudah dianggap usai. Padahal pesta demokrasi sejatinya tidak berhenti kepada titik pemilihan pemimpin saja tetapi lebih subtstantif mempertanyakan bentuk komitmen nyata pemimpin daerah yang terpilih untuk memenuhi hasrat mensejahterakan rakyat yang kerap kali diusung dalam janji kampanyenya. Inilah bentuk responsivitas yang acapkali 
menentukaan dinamika pilkada berikutnya, yaitu petahana yang sukses menjalankan program-programnya dapat mendulang kemenangan dengan telak pada pilkada berikutnya.

Ada banyak tulisan tentang pilkada di Indonesia dalam karya-karya ilmiah sebelumnya, tetapi yang khusus membahas pilkada dengan demokrasi lokal belum banyak. Fitriyah (2011) lebih memfokuskan diri kepada studi proses pilkada langsung yang diyakininya dapat memberikan ruang kepada demokratisasi di Indonesia (Fitriyah, 2011) Secara diametral pendapatnya berbeda dengan Retno Saraswati (2014) yang beragumen bahwa pilkada langsung justru tidak mendatangkan kesejahteraan rakyat karena problem yang dihasilkan jauh dari unsur-unsur demokrasi. Pelaksanaan pilkada langsung juga dipertanyakan efektifitasnya oleh Iza Rumesten RS (2014), karena pada kenyataanya banyak melahirkan koruptorkoruptor baru. Studi pilkada dengan demokrasi lokal juga dibahas oleh Fatkhrohman (2010) yang menyoroti kelemahan pikada langsung sehingga memunculkan serangkaian korupsi yang pada gilirannya memerosotkan demokrasi (Fatkhurohman, 2010). Janpatar Simamora (2011) lebih optimis melihat pilkada langsung sebagai proses pematangan demokrasi di tingkat daerah, kendati dalam pelaksanaannya banyak menimbulkan masalah (Simamora, 2011). Dalam kaitan dengan demokrasi lokal, Yana Syafriana Hijri (2008), membahas peranan Komisi Pemilihan Umum Daerah (KPUD) di Kota Malang yang memiliki peranan penting dalam memperkuat demokrasi lokal berkat peran krusialnya sebagai penyelenggara pilkada (Hijri, 2008). Dari rangkaian Kajian Pustaka tersebut belum ada yang membahas pilkada dan demokrasi lokal dari sisi partisipasi dan responsivitas. Oleh karena itu diharapkan tulisan ini mampu mengisi kekosongan studi demokrasi lokal dan pilkada di Indonesia.

Untuk lebih jauh membahas pilkada dalam kaitannya dengan proses demokrasi lokal, sebagai landasan pemahaman yang utuh maka penjelasan konseptualisasi menjadi asas pembahasan pilkada dan demokrasi lokal. Penting untuk mengemukakan landasan konsepsional karena diharapkan tulisan ini dapat menganalisa pilkada dalam konteks pelaksanaan demokrasi lokal secara lebih argumentatif. Sebagai permulaan maka pembahasan demokrasi lokal penulis kemukakan dibawah ini.

\section{Kajian Pustaka}

\section{Demokrasi Lokal di Indonesia}

Memahami demokrasi lokal memang tak dapat memisahkan diri dari perbincangan tentang kebijakan desentralisasi. Mengingat kebijakan ini merupakan pintu awal bagi terciptanya demokrasi lokal. Bahkan sejumlah ilmuwan meyakini bahwa tujuan yang sesungguhnya dari desentralisasi tidak lain 
adalah menumbuhkan demokrasi lokal. ${ }^{93}$ Dalam konteks ini salah satu bentuk kebijakan desentralisasi yang sangat penting bagi kelangsungan demokrasi lokal adalah devolusi, yakni transfer kekuasaan, kewenangan, tanggung jawab dan sumberdaya dari negara ke pemerintah lokal. Devolusi juga sering disebut dengan desentralisasi demokratis (democratic decentralization), yakni sebagai bentuk pengembangan hubungan sinergis antara pemerintah pusat dengan pemerintah daerah dan antara pemerintah daerah dengan warga masyarakat. Desentralisasi demokratis hendak mengelola kekuasaan untuk mengembangkan dan mengimplementasikan kebijakan, perluasan proses demokrasi pada level pemerintahan lokal, dan mengembangkan standar (ukuran) yang menjamin bahwa demokrasi berlangsung secara berkelanjutan (Manor, 1997). Adapun kebijakan desentralisasi yang lain adalah dekosentrasi, yang mengacu pada penggeseran pembuatan keputusan (decisionmaking) dalam negara, dan delegasi tugastugas tertentu sementara pemerintah pusat masih menguasai tanggung jawab keseluruhan. Sementara itu privatisasi adalah merupakan bentuk desentralisasi yang paling jauh jangkauannya (Freks dan Otto, 1996).

93 Brian C. Smith, Decentralization: Territory Dimension of the State (London: MacMillan, 1985); Dennis Rondinelli, "What is Decentralization?" Note prepared for the PREM Knowledge Management System, World Bank, Washington, DC, 1998; dan Larry Diamond, Developing Democracy (Baltimore and London: The Johns Hopkins University Press, 1999), bab 4.
Keyakinan bahwa desentralisasi akan menumbuhkan demokrasi lokal juga dianut oleh Robert Putnam. $^{94}$ Menurutnya desentralisasi menumbuhkan partisipasi dan tradisi kewargaan di tingkat lokal. Partisipasi demokratis warga telah melahirkan komitmen warga yang luas maupun hubungan-hubungan horisontal: kepercayaan (trust), toleransi, kerjasama, dan solidaritas yang membentuk apa yang disebut Putnam komunitas sipil (civic community). Indikator-indikator civic engagement -- solidaritas sosial dan partisipasi massal - dapat berpengaruh terhadap kinerja pembangunan sebagai contoh kinerja pembangunan ekonomi dan kualitas kehidupan demokratis. Selama seperempat abad terakhir, desentralisasi politik di Itali telah secara luas mentransformasikan kultur politik elite dalam suatu arah yang demokratis. Pembentukan pemerintahan regional, yang kemudian mendapatkan sejumlah kekuasaan otonom yang signifikan dan kontrol atas sumber-sumber daya, menghasilkan suatu tipe perpolitikan yang secara ideologis tidak terlalu terpolarisasi, lebih moderat, toleran, pragmatis, lebih fleksibel dan suatu 'penerimaan mutual yang lebih besar di antara hampir semua partai'. Secara berangsur-angsur warga mulai mengidentifikasi diri dengan level

94 Robert Putnam, Making Democracy Work: Civic Tradition in Moden Italy (Princeton, New Jersey: Princeton University Press, 1993). Ide Putnam tentang civic community ini sangat dipengaruhi oleh aliran republikanisme dan pemikiran Tocqueville tentang kehidupan asosiasional sebagai basis demokrasi di Amerika Serikat. Lihat Alexis de Tocqueville, Democracy in America, ed. J.P. Mayer (Garden City, NY: Anchor Books, 1969 
pemerintahan lokal dan bahkan lebih menghargainya ketimbang pemerintahan nasional.

Kajian demokrasi lokal secara lebih detail diberikan oleh organisasi nonpemerintah global yatu International IDEA. ${ }^{95}$ Sebagai organisasi yang bergerak di bidang penelitian dan advokasi pemberadaayan demokrasi, International IDEA banyak membantu memberikan analisa dan penjelasan tentang demokrasi lokal yaitu dengan menekankan kepada konspesi penting sebagai berikut:

\section{Kewarganegaraan} dan

masyarakat. Peran serta masyarakat lokal sesungguhnya adalah fondasi utama dalam gagasan modern mengenai kewarganegaraan, sebab lembaga-lembaga masyarakat yang ada beserta segala proses pengambilan keputusannya memungkinkan terwujudnya praktik demokrasi yang lebih langsung, dimana suara individu dapat didengar dengan lebih mudah. (2) Musyawarah. Demokrasi bukanlah semata berarti pemilu. Di dalamnya terkandung unsur-unsur penting seperti dialog, debat, dan diskusi yang bermakna guna mencari solusi bagi segala masalah yang timbul di dalam masyarakat. Perundingan atau musyawarah juga bukan sekadar mendengar dan menampung keluhan warga. Demokrasi berdasar musyawarah pasti melibatkan dialog yang bersifat saling

\footnotetext{
${ }^{95}$ International IDEA adalah sebuah Lembaga Swadaya Masyarakat (LSM) Internasional yang menumpukan perhatian kepada penelitian bidang ilmu kemasyarakatan dan pemberdayaan demokrasi. Situsnya dapat dapat dilayari di : http://www.idea.int.
}

memberi dan menerima antarkelompokkelompok kepentingan dalam masyarakat tentang keputusan-keputusan terpenting dan tindakan-tindakan yang mereka hadapi dan tanggung bersama-sama. (3) Pendidikan politik. Demokrasi lokal akan memberi fasilitas bagi proses pendidikan politik. Peran serta warga masyarakat memungkinkan setiap individu memperoleh informasi mengenai semua urusan dan masalah di masyarakat, yang, jika tidak, hanya diketahui oleh pejabat terpilih atau para profesional pemerintahan di kantor walikota. Penduduk yang terdidik dan memiliki informasi akan menciptakan demokrasi -yang berarti pengambilan keputusan oleh rakyat- semakin mungkin dan efektif. Peran serta masyarakat berarti mengurangi jurang pemisah antara para elite politik dan anggota masyarakat. Pemerintah yang baik dan kesejahteraan sosial. John Stuart Mill dan para pendukung paham demokrasi partisipatoris di tingkat lokal berpendapat bahwa membuka keran bagi kebijakan dan kecerdasan masyarakat akan mendukung terciptanya pemerintahan yang baik serta mendukung tercapainya kesejahteraan sosial. Artinya, demokrasi cenderung meningkatkan hubungan yang baik antarwarga, membangun masyarakat yang mandiri dan memiliki semangat sosial (Sisk, et al., 2002).

Kebijakan desentralisasi dan otonomi daerah di Indonesia yang diawali dengan dikeluarkannya UU No. 32/1999 dan direvisi dengan UU baru yaitu UU No.32/2004 adalah 
wujud keseriusan pemerintah untuk mengembangkan demokrasi pada level lokal. Usaha ini tidak lain adalah wujud pemenuhan amanah reformasi yang ingin mengembangkan demokrasi lebih luas. Semangatnya lebih tertuju kepada ingin melepaskan diri dari bayang-bayang warisan otoriterisme yang membelenggu partisipasi dan pengembangan demokrasi di level lokal.

Uraian diatas jelas menunjukkan bahwa teorisasi demokrasi lokal masih tergolong berserakan. Maka di bawah ini penulis akan merangkaikan sebuah pemahaman yang dapat membantu menjelaskan teorisasi demokrasi lokal yang mencukupi. Dalam sebuah disertasinya, Suyatno (2011) mencoba memberikan alternatif penjelas dalam sebuah model yang menggabungkan filsafat demokrasi, sistem politik "Easton"96 dan faktor-faktor implementasi demokrasi yang lebih terperinci. Model ini oleh Suyatno disebut sebagai Model Implementasi Demokrasi, yang diharapkan bisa memperjelas pelaksanaan demokrasi

96 David Easton, "An Approach to the Analysis of Poitical Systems", dalam World Politics IX, No. 3 (April 1957). Easton mengusulkan suatu metode untuk menganalisis berbagai jenis sistem politik, yaitu dengan mengkaji sistem-sistem politik yang berdasarkan ciri-ciri utama: (1) kesatuan-kesatuan yang membentuk sistem itu dan luasnya batas-batas pengaruh sistem itu, (2) "input" dan "output" dari sistem yang tercermin dalam keputusan-keputusan yang dibuat (output) dan proses pembuatan keputusan (input) di dalam sistem tersebut, (3) jenis dan tingkat perbedaan (diferensiasi) dalam sistem tersebut, dan (4) tingkat integrasi sistem politik yang mencerminkan tingkat efisiensinya. Dengan menganalisis berbagai bagian ini, Easton menawarkan sebuah metode untuk memahami dan membandingkan berbagai sistem politik. Lihat Mochtar Mas'oed dan Collin McAndrews, Perbandingan Sistem Politik (Yogyakarta: Gadjah Mada University Press, 2001). dalam konteks hubungan negara dan masyarakat.

Sebagaimana diyakini bersama bahwa filsafat demokrasi yang paling mendasar, yang dipopulerkan oleh Abraham Lincoln, tidak lain adalah "dari rakyat", "oleh rakyat" dan "untuk rakyat". Karena masih bersifat nlainilai falsafah maka hal ini memerlukan alat yang sukses meletakkan filsafat tersebut agar bisa dijalankan lebih nyata. Suyatno menggunakan sistem politik "Easton" untuk menampung filsafat agar bisa dijalankan dalam sebuah sistem politik. Terdiri dari tiga bagian yang mampu menampung nilai-nilai filsafat, yaitu input, proses dan output. Melalui sistem ini dimana "input", yang menerjemahkan nilai filsafat "dari rakyat", akan menghasilkan apa yang dinamakan dengan keterwakilan dan partisipasi. "Proses" yang menerjemahkan filsafat "oleh rakyat", akan menghasilkan institusi yang disebut dengan kemitraan, transparansi dan kebertanggungjawaban. Sedangkan bagian "output", yang menerjemahkan filsafat "untuk rakyat" akan memunculkan institusi responsivitas (Suyatno, 2011).

Untuk keperluan tulisan ini, penulis akan membatasi diri dengan menggunakan konsepsi partisipasi dan responsivitas dengan argumen bahwa pilkada memiliki pesan kuat untuk merefleksikan bentuk partisipasi warga dalam memilih pemimpinnya, sehingga menjadi wajar jika melihat proses pilkada begitu semarak dan gempita di berbagai daerah karena antusiasme pemilih begitu 
besar. Sementara itu, kadar responsivitas menunjukkan betapa pentingnya fase setelah pilkada bisa dapat dijadikan tolok ukur bagi berjalannya demokrasi lokal. Beberapa petahana sukses mendulang kemenangannya dalam pilkada, sesungguhnya tidak lain ditentukan oleh salah satu faktor yaitu kadar responsivitas yang teruji dan terbukti selama kepemimpinannya. Alasan lain adalah terbatasnya ruang yang tersedia dalam tulisan kali ini untuk menggunakan konsepsi lain, seperti keterwakilan, kemitraan, transparansi dan kebertanggungjawaban, untuk membahas pilkada dan demokrasi lokal. Oleh karena itu pembahasan partisipasi akan menjadi diskusi yang menarik jika dikaitkan dengan pilkada yang dijalankan selama ini.

\section{Temuan dan Diskusi}

\section{Demokrasi Lokal dan Partisipasi}

Filsafat demokrasi "dari rakyat" jika diletakkan dalam sistem politik Easton maka masuk dalam kategori "input", dan implementasinya akan melahirkan konsep partisipasi dan keterwakilan. Partisipasi adalah persoalan hubungan kekuasaaan, atau hubungan ekonomi-politik, yang dianjurkan oleh demokrasi. Partisipasi rakyat berada dalam konteks hubungan antara negara (pemerintah) dan rakyat (masyarakat). Negara adalah pusat kekuasaan, kedaulatan dan serangkaian hukum yang mengatur peredaran barang-barang publik di masyarakat. Di dalam masyarakat sendiri terdapat hak sipil dan hal politik, kekuatan kelompok, kebutuhan hidup, dan lain-lain. Dengan demikian, partisipasi adalah jembatan penghubung antara negara dan masyarakat agar pengelolaan barangbarang publik melahirkan kesejahteraan manusia (human well being) (Suyatno, 2011).

Dari sudut pandangan negara, demokrasi mengajarkan bahawa partisipasi sangat diperlukan untuk membangun pemerintahan yang akuntabel, transparan, dan responsif terhadap kebutuhan masyarakat. Tiadanya partisipasi hanya akan menabur pemerintahan yang otoriter dan korup. Sementara itu dari sisi masyarakat, partisipasi adalah kunci pemberdayaan (empowerment). Partisipasi memberikan ruang dan kapasitas masyarakat untuk memenuhi kebutuhan dan hak-hak mereka, mengembangkan potensi dan inisiatif lokal, mengaktifkan peranan masyarakat serta membangun masyarakat yang mandiri.

Dalam konteks hubungan tersebut, partisipasi meletakkan masyarakat kepada posisi yang sebenarnya. Pertama, masyarakat bukanlah sebagai budak (client) melainkan sebagai warga (citizen). Jika budak memperlihatkan kepatuhan secara total, tetapi kalau konsep warga menganggap bahwa setiap individu adalah pribadi yang utuh dan mempunyai hak penuh untuk memiliki. Kedua, masyarakat bukan dalam kedudukan yang diperintah tetapi sebagai mitra (partner) pemerintah dalam mengurus pemerintahan dan pembangunan. Ketiga, partisipasi bukanlah pemberian pemerintah tetapi sebagai hak warga masyarakat itu sendiri. Keempat, 
masyarakat bukan sekadar obyek pasif penerima manfaat kebijakank pemerintah, tetapi sebagai aktor atau subyek yang aktif menentukan kebijakan. ${ }^{97}$ Ini yang menjelaskan kenapa pilkada diselenggarakan secara merata di wilayah Indonesia. Kesadaran demokratis menempatkan pentingnya partisipasi masyarakat dalam kedudukan yang sebenarnya dalam proses pemilihan pemimpin. Ada kuasa politik dari rakyat untuk ikut menentukan pilihan terbaik pemimpinnya dalam mekanisme pemilihan umum.

Namun begitu fase lain dari demokrasi yang tak kalah pentingnya adalah Responsivitas (Responsiveness). Menjadi jelas bahwa apakah demokrasi sudah dijalankan sebagaimana mestinya memenuhi kebutuhan rakyat guna mencapai keinginan membangun kesejahteraan bersama, maka responsivitas menjadi argumen pamungkas dari proses pilkada secara menyeluruh. Untuk itu dibawah ini akan dijelaskan penjeasan repsonsivitas untuk melengkapi pembahasan tentang Pilkada secara lebih lengkap.

\section{Demokrasi Lokal dan Responsivitas}

Implementasi falsafah "untuk rakyat" yang didalam sistem politik dapat diketahui dalam bentuk output. Dalam demokrasi, output ini yang menginstitusikan apa yang dikenal dengan sebutan responsivitas (responsiveness). Responsivitas merujuk

97 Sutoro Eko, Voice, Akses, dan Kawalan Masyarakat, makalah dalam www.ireyogya.org/sutoro/voice_dan_ akses_masyarakat.pdf. (2 Februari 2006) kepada cara mana sesuatu yang diberikan oleh pengambil keputusan -baik umum ataupun perseorangan-- dalam merespons keperluan dan menjalankannya ke dalam tuntutan kelompoknya, seperti kasus kemiskinan misalnya. ${ }^{98}$

Karena merupakan hasil implementasi "untuk rakyat", maka responsiviti dapat dipahami secara lekat dengan hasil pelayanan publik atau masyarakat, melalui serangkaian kebijakan yang ditempuh. Dalam kaitan ini responsivitas diartikan sebagai kemampuan birokrasi untuk mengenali kebutuhan masyarakat, menyusun agenda dan prioritas pelayanan, serta mengembangkan rancanganrancangan perkhidmatan sesuai dengan keperluan dan aspirasi masyarakat. Secara singkat dapat dikatakan bahwa responsivitas ini mengukur kualitas responsif birokrasi terhadap harapan, keinginan dan aspirasi, serta tuntutan layanan pengguna (service user). Responisivitas sangat diperlukan dalam pelayanan publik karena hal tersebut merupakan bukti kemampuan organisasi untuk mengetahui kebutuhan masyarakat, menyusun agenda dan prioritas pelayanan serta mengembangkan rencana-rencana pelayanan publik sesuai dengan keperluan aspirasi masyarakat. Organisasi yang memiliki responsivitas yang rendah dengan

98 Siri Gloppen, Lise Rakner and Arne Tostensen, Responsiveness to the Concerns of the Poor and Accountability to the Commitment to Poverty Reduction, dalam http://www.undp.org/oslocentre/ PAR_Bergen_2002/concerns-poor-issues-paper.pdf. (20 Januari 2015). 
sendirinya memiliki kinerja yang buruk juga (Dwiyanto, dkk, 2011).

Kebijakan yang responsif adalah kebijakan yang dibuat sebagai respons terhadap aspirasi atau kebutuhan dasar masyarakat. Memberantas kemiskinan dan buta huruf, meningkatkan taraf hidup, menjamin kesehatan, menyediakan pendidikan yang terjangkau, memberikan pinjaman usaha kecil dan sebagainya, adalah contoh kebijakan yang dikenal dengan sebutan kebijakan yang berpihak kepada masyarakat miskin (pro poor policy). Juga kebijakan yang diambil kerana respons terhadap kebutuhan peningkatan kapasitas ekonomi dengan memberikan lapangan pekerjaan yang lebih luas (pro jobs) dan mendorong laju perekonomian lebih cepat (pro growth) agar peringkat kesejahteraan masyarakat semakin tercapai. Ini adalah selaras dengan implementasi falsafah "untuk rakyat" bukan untuk sekumpulan elit penguasa, dimana masyarakat tetap miskin tetapi para penguasanya kaya raya (pro elit). Capaian ini tentunya bergantung kepada kapasitas pencapaian yang diawali dari falsafah "dari rakyat" dan "oleh rakyat" melalui pengolahan kepada sistem politik dari implementasi "input" menuju "proses" yang kepada gilirannya menentukan kualitas "output" yang dilahirkan dalam bentuk responsivitas (Suyatno, 2011).

Pilkada banyak melahirkan pemimpin baru yang memiliki serangkaian janji program yang nantinya dijalankan dalam kebijakan publik dengan sasaran kesejahteraan rakyat sebagai tujuan akhir. Bentuk responsivitas sangat menentukan kualitas demokrasi lokal karena menggambarkan dinamika kesuksesan pemimpin terpilih dan masyarakt memilih dalam komunikasi dan aksi politik yang menguntungkan. Ini yang menjelaskan ketika masyarakat puas hati dengan kepemimpinan lokal yang dianggap responsif terhadap kebutuhan masyarakat, maka menjadi amat wajar jika pada pilakda berikutnya akan dipilih kembali dengan suara yang amat meyakinkan, mutlak. Kasus terpilihnya Azwar Anas di Banyuwangi dan Tri Rismaharini di Surabaya untuk kedua kalinya sebagai kepala daerah menjadi salah satu kisah sukses pemimpin yang responsif dengan pilkada yang partisipatif.

\section{Pilkada, Partisipasi dan Responsivitas}

Pilkada langsung pada akhirnya menggantikan pilkada tidak langsung didasari oleh semangat pemberdayaan masyarakat dalam berpartisipasi memilih kepala daerah secara lebih demokratis. Namun harus diakui pemilihan langsung sesungguhnya merupakan tindak lanjut realisasi prinsip-prinsip demokrasi secara normatif yakni jaminan atas bekerjanya prinsip kebebasan individu dan persamaan, khususnya dalam hak politik (Pratikno, 2005). Maswadi Rauf (2005) menyebutkan ada empat alasan mengapa pilkada langsung perlu digelar menggantikan pilkada tidak langsung. Pertama, untuk membangun daerah; kedua menumbuhkan 
kepemimpinan lokal; ketiga, meningkatkan akuntabilitas publik dan transparansi pemerintah; dan keempat adalah proses legitimasi rakyat yang kuat.

Ada beberapa implikasi yang menguntungkan pemilih dan pemimpin yang dipilih karena partisipasi langsung dalam pemilihan karena menyiratkan tiga hal berikut: pertama, kepala daerah punya legitimasi kuat untuk memerintah. Kedua, pilkada langsung lebih menjamin stabilitas pemerintahan daerah, karena masa kerja kepala daerah pasti yang tidak bisa dijatuhkan oleh DPRD. Ketiga, probabilitas aspirasi publik yang terserap lebih tinggi karena keterpilihannya ditentukan suara pemilih (Fitriyah, 2011). Dengan begitu pilkada langsung memang menggambarkan pelaksanaan partisipasi yang kuat. Tidak saja pemerintah lokal yang dibentuk menjadi kuat karena legitimasi politik yang didapat melalui pemilihan langsung, sehingga tidak lagi begitu mudah digoyang oleh DPRD, tetapi juga pemerintah lokal memiliki modal politik yang kuat untuk membangun daerahnya. Dari sisi masyarakat, partisipasinya dalam pilkada langsung mendorong adanya ruang pemberdayaan politik secara signifikan. Tidak saja masyarakat ikut menentukan pemimpin lokal melalui suara pemilih tetapi juga terlibat dalam proses partisipasi politik melalui persetujuannya terhadap program-program calon pemimpin yang disetujuinya dalam bentuk keputusan pilihan suaranya.
Namun begitu temuan Badan Pengawas Pemilihan Umum (Bawaslu) Republik Indonesia dalam pernyataan persnya memberikan keterangan yang mengejutkan tentang partisipasi pemilih dalam pilkada. Bawaslu menyatakan bahwa meskipun pelaksanaan Pemilu/Pemilihan Kepala Daerah sudah semakin demokratis, yakni ditandai dengan semakin transparannya proses (predictable process) dan hasilnya tidak bisa diprediksi (unpredictable result) tetapi dari pelaksanaan pemilu ke pemilu, partisipasi masyarakat cenderung menurun. Bisa jadi ini merupakan bentuk apatisme masyarakat terhadap pemilu, yang dinilai tidak memberikan perubahan yang signifikan bagi kesehjateraan mereka. ${ }^{99}$

Ketika masyarakat terlibat langsung dalam menentukan pilihan politiknya untuk pemimpin di daerahnya, maka wajar jika mucul bentuk respon terhadap programprogram secara langsung. Tindakan yang dilakukan oleh pemilih tidak lain berwujud 'stick and carrot' dalam pilkada berikutnya. Jikalau pemimpin lokal yang terpilih mampu memberikan responsivitas sebagaimana yang diharapkan masyarakat, maka respon positif (carrot) akan diberikan dalam bentuk suara dalam pilkada. Namun sebaliknya jika dianggap tidak responsif dengan kebutuhan masyarakat, maka "hukuman" (stick) akan

99 Badan Pengawas Pemilihan Umum Republik Indonesia, Pilkada Semakin Demokratis Tapi Partisipasi Cenderung Menurun, Selasa, 10 November 2015, dalam http://bawaslu.go.id/id/berita/pilkada-semakindemokratis-tapi-partisipasi-cenderung-menurun. D unduh pada 1 Mei 2016. 
diberikan dalam wujud tidak memilih atau apatis (golput) dalam pilkada.

$$
\text { Kemenangan petahana yang }
$$
dianggap mampu menjalankan kebijakan publik dengan baik, menjadi pertanda bahwa partisipasi masyarakat diberikan secara penuh dalam pilkada. Perhimpunan untuk Pemilu dan Demokrasi (Perludem) menyebutkan dari 538 calon kepala dan calon wakil kepala daerah yang maju dalam pilkada serentak 2015 ini, 278 orang atau lebih dari separuh di antara mereka merupakan mantan gubernur, bupati dan wali kota ataupun wakilnya. Dalam hitung cepat yang dilakukan Lembaga Survey Indonesia (LSI) dan sejumlah lembaga, sejumlah pasangan petahana tampak mendapatkan perolehan suara terbanyak, bahkan di beberapa daerah mereka menang telak. Antara lain pasangan calon wali kota dan wakil wali kota Surabaya, Tri Rismaharini-Wisnu Sakti Surya. Lalu, di Banyuwangi, pasangan mantan Bupati Abdullah Azwar Anas-Yusuf Widyatmoko memperoleh suara sampai $88,78 \%$, berdasarkan survei LSI. ${ }^{100}$

Ini semakin memperkuat argumen bahwa tingginya angka partisipasi belumlah menjamin bahwa pilkada sukses mengimplementasikan prinsip demokrasi. Substansinya tidak lain adalah sejauh mana rangkaian proses pilkada yang direpresentasikan dalam bentuk partisipasi

100 BBC Indonesia, Pilkada serentak, sejumlah calon petahana unggul, dalam http://www.bbc.com/ indonesia/berita_indonesia/2015/12/151210_indonesia_ pilkada_petahana. Di unduh pada 1 Mei 2016. bisa berlangsung secara sempurna dengan menyertakan variabel responsivitas pemimpin lokal. Pengalaman pilkada menunjukkan betapa tingginya angka partisipasi di masa Orde Baru berbanding dengan masa reformasi, tetapi sesungguhnya menunjukkan adanya partisipasi semu, karena partisipasinya didorong oleh mobilisasi pemerintah.

Hal ini seiring dengan pernyataan bahwa mobilisasi masyarakat secara top-down bukanlah bentuk partisipasi yang sejati. Soebagio menyatakan bahwa beberapa studi secara eksplisit tidak menganggap tindakan yang dimobilisasikan atau yang dimanipulasikan sebagai partisipasi politik, yaitu lebih menekankan sifat sukarela dari partisipasi dengan argumentasi bahwa menjadi anggota organisasi atau menghadiri rapat-rapat umum atas perintah pemerintah tidak termasuk partisipasi politik (Soebagio, 2008). Di masa Orde Baru partisipasi politik yang dimobilisasikan merupakan kontribusi hasil mobilisasi politik yang dilakukan oleh jaringan aparat birokrasi pemerintahan Orde Baru, bersinergi dengan dukungan pengaruh para tokoh-tokoh masyarakat karismatik sebagai panutan yang telah dikooptasi oleh birokrasi pemerintahan sebagai wasit, namun ikut bermain politik sebagai orang Golkar.

Dengan begitu perilaku golput dalam hemat penulis juga merupakan partisipasi politik karena merefleksikan sikap bukan sebagai budak (client) melainkan sebagai warga (citizen) dan menganggap partisipasi bukanlah pemberian pemerintah tetapi sebagai 
hak warga masyarakat itu sendiri, baik berpartisipasi untuk memilih dan berpartisipasi untuk tidak memilih. Justru dengan meningkatnya jumlah golput menandakan keberanian masyarakat bersuara (voice) untuk merespon tindakan pemimpin yang dipilih dalam pilkada sebelumnya. Ini adalah manifestasi demokrasi juga.

Secara empirik peningkatan angka Golput tersebut terjadi antara lain oleh realitas sebagai berikut: (1). Pemilu dan Pilkada langsung belum mampu menghasilkan perubahan berarti bagi peningkatan kesejahteraan masyarakat; (2). Menurunnya kinerja partai politik yang tidak memiliki platform politik yang realistis dan kader politik yang berkualitas serta komitmen politik yang berpihak kepada kepentingan publik, melainkan lebih mengutamakan kepentingan kelompok atau golongannya; (3). Merosotnya integritas moral aktor-aktor politik (elit politik) yang berperilaku koruptif dan lebih mengejar kekuasaan/kedudukan daripada memperjuangkan aspirasi publik; (4) Tidak terealisasikannya janji-janji yang dikampanyekan oleh elit politik kepada publik yang mendukungnnya; (5). Kejenuhan pemilih karena sering adanya Pemilu/Pilkada yang dipandang sebagai kegiatan seremonial berdemokrasi yang lebih menguntungkan bagi para elit politik; (6). Kurang netralnya penyelenggara Pemilu/Pilkada yang masih berpotensi melakukan keberpihakan kepada kontestan tertentu, di samping juga kurangnya intensitas sosialisasi Pemilu secara terprogram dan meluas (Soebagio, 2008).

Dari uraian diatas nampak jelas betapa unsur responsivitas menjadi salah satu unsur terpenting kelangsungan partisipasi masyarakat untuk melanjutkan pilihannya terhadap petahana. Jika peningkatan jumlah gotput dari masa Orde Baru (rata-rata dibawah 10 persen) ke masa reformasi (ratarata antara $30-40$ persen) menjadi pertanda melemahnya partisipasi aktif pemilih untuk menentukan pilihannya, dalam konteks ini bisa dikatakan justru ada keberanian pemilih untuk tidak memilih karena alasan tertentu. Dengan kata lain merupakan respon terhadap responsivitas pemimpin lokal.

Fenomena lain selain golput yang menunjukkan adanya penurunan partisipasi aktif dan dengan sendirinya menunjukkan keberanian untuk berpartisipasi pasif (golput) dari masyarakat, yaitu kemenangan petahana dalam pilkada 2015 yang mencapai lebih dari $50 \%$ pilkada di seluruh Indonesia. Dari pilkada yang diselenggarakan di 269 daerah, ternyata lebih banyak calon petahana yang memenangkan pilkada daripada yang kalah, dengan perbandingan 57,9 persen dan 42,1 persen. Petahana yang berhasil mempertahankan atau meraih kembali posisinya sebagai kepala daerah lebih banyak terjadi di wilayah kota daripada kabupaten. Di kota, walikota yang berhasil mempertahankan posisinya mencapai 47,1 persen, sementara di kabupaten hanya 28,1 persen bupati yang kembali meraih posisi sebagai kepala 
daerah. ${ }^{101}$ Data ini seolah menguatkan argumentasi bahwa petahana memiliki peluang menang lebih besar daripada pesaingnya. Pada pilkada sebelumnya dari data yang dihimpun, selama kurun waktu tahun 2011 saja, dari sekitar 211-an pelaksanaan pilkada di berbagai daerah di Indonesia, 124 daerah atau 59,05\% dimenangkan kembali oleh calon incumbent (petahana), sementara 87 daerah lainnya atau sekitar 40,05\% calon incumbent mengalami kekalahan.

Tabel dibawah ini menjelaskan kemenangan yang diraih petahan dengan suara yang cukup telak.

Tabel 1.0

10 Besar Petahana Menang Pilkada 2015

\begin{tabular}{|c|c|c|c|}
\hline $\begin{array}{l}\text { No } \\
\text {. }\end{array}$ & Daerah & $\begin{array}{c}\text { Nama } \\
\text { Pasangan } \\
\text { Petahana }\end{array}$ & $\begin{array}{c}\text { Persentase } \\
\text { Kemenanga } \\
\text { n }\end{array}$ \\
\hline 1. & Kota Blitar & $\begin{array}{l}\text { Samanhudi } \\
\text { Anwar- } \\
\text { Santoso }\end{array}$ & 92,04 \\
\hline 2. & $\begin{array}{l}\text { Kutai } \\
\text { Kartanegar } \\
\text { a }\end{array}$ & $\begin{array}{c}\text { Rita } \\
\text { Widyasari- } \\
\text { Edi } \\
\text { Damansyah }\end{array}$ & 89,40 \\
\hline 3. & $\begin{array}{l}\text { Banyuwan } \\
\text { gi }\end{array}$ & $\begin{array}{c}\text { A Azwar } \\
\text { Anas-Yusuf } \\
\text { W }\end{array}$ & 88,96 \\
\hline 4. & $\begin{array}{l}\text { Bandar } \\
\text { Lampung }\end{array}$ & $\begin{array}{l}\text { Herman H.N- } \\
\text { Muhammad } \\
\text { Yusuf Kohar }\end{array}$ & 86,66 \\
\hline 5. & Surabaya & $\begin{array}{c}\text { Tri } \\
\text { Rismaharini- } \\
\text { Whisnu Sakti } \\
\text { Buana }\end{array}$ & 86,22 \\
\hline 6. & Denpasar & I.B.R. & 82,19 \\
\hline
\end{tabular}

101 Kompas, "Petahana Tetap Kuat di Pilkada 2015", dalam http://nasional.kompas.com/read/2016/01/07 102205431/Petahana.Tetap.Kuat.di.Pilkada.2015. Di unduh pada 5 Mei 2016.

\begin{tabular}{|c|c|c|c|}
\hline & & $\begin{array}{c}\text { Dharmawijay } \\
\text { a-I.G.N. Jaya } \\
\text { Negara }\end{array}$ & \\
\hline 7. & $\begin{array}{l}\text { Tanah } \\
\text { Bumbu }\end{array}$ & $\begin{array}{l}\text { Mardani H } \\
\text { Maming- } \\
\text { Sudian Noor }\end{array}$ & 81,50 \\
\hline 8. & Mojokerto & $\begin{array}{c}\text { Mustafa } \\
\text { Kamal Pasa- } \\
\text { Pungkasiadi }\end{array}$ & 78,65 \\
\hline 9. & $\begin{array}{l}\text { Bolmong } \\
\text { Selatan }\end{array}$ & $\begin{array}{l}\text { Herson } \\
\text { Mayulu- } \\
\text { Iskandar } \\
\text { Kamaru }\end{array}$ & 77,35 \\
\hline 10. & Medan & $\begin{array}{c}\text { Dzulmi Edin- } \\
\text { Akhyar } \\
\text { Nasution }\end{array}$ & 71,68 \\
\hline
\end{tabular}

mbak Rita, http://www.jpnn.com/read/2015/12/13/3443

71/Ibu-Risma-di-Bawah-Mbak-Rita-/page3. Diunduh pada 5 Mei 2016

Banyak faktor yang menyebabkan kemenangan petahana. Peneliti LSI, Ardian Sopa mengatakan, setidaknya ada lima faktor yang membuat calon petahana mampu memenangi pilkada serentak tahun ini. Pertama adalah karena masyarakat merasa puas atas kinerja kepemimpinannya selama menjabat. Kedua, pasangan petahana sudah lebih dikenal oleh masyarakat. Para pasangan incumbent biasanya sudah lebih populer, itu juga bisa menjadi faktor kemenangannya. Ketiga, pasangan petahana dianggap telah menguasai dan mampu menjangkau semua segmen pemilih. Keempat, pasangan petahana mampu menggerakkan tokoh informal maupun formal. Kelima, pasangan petahana dianggap lebih siap secara finansial. Selama menjabat, biaya hidup petahana ditanggung oleh negara, maka wajar jika mamapu mengumpulkan dari hasil selama menjabat 
kepala daerah untuk menghadapi pilkada tahun ini. ${ }^{102}$

Kisah sukses kepemimpinan Tri Rismaharini sebagai walikota Surabaya dan Azwar Anas sebagai bupati Banyuwangi menjadi contoh betapa masyarakat di kedua daerah tersebut memberikan kesempatan kepada petahana untuk memimpin daerahnya kedua kali. Risma mampu merebut suara 86,22 persen dari pemilihnya, sedangkan Azwar Anas sukses mendulang 87,88 persen. Kedua petahana ini sebelumnya memang tergolong sangat populer di media masa karena kebijakan publiknya yang dianggap inovatif dan menyentuh masyarakat langsung.

Risma dikenal dengan kebijakan publik yang membawa Surabaya sukses meraih Piala Adipura selama 4 tahun berturutturut. Audit BPK pada tahun 2013 juga memberikan opini Wajar Tanpa Pengecualian (WTP) terhadap Laporan Keuangan Pemerintah Daerah Kota Surabaya Tahun Anggaran 2013. Opini WTP merupakan penilaian tertinggi yang diberikan oleh auditor terhadap hasil auditnya yang berarti bahwa Pemkot Surabaya mampu mengelola keuangannya secara wajar, baik, transparan dan akuntabel. Selain itu Walikota Surabaya tersebut mengeluarkan kebijakan penggunanaan sistem e-budgeting dalam pengelolaan APBD Kota Surabaya. Sistem ebudgeting Pemkot Surabaya ini diakui

102 Dedy Priatmojo, Lima Faktor Calon Petahana Unggul di Pilkada Serentak, dalam http://politik.news.viva. co.id/news/read/709835-lima-faktor-calon-petahanaunggul-di-pilkada-serentak. Diunduh pada 5 Mei 2016. keberhasilannya sehingga diadopsi oleh daerah-daerah lain di Indonesia. Kemampuan Risma membangun citranya di media massa juga menjadi salah satu penentu karena popularitas akan memudahkan pemilih untuk memilihnya kembali. Salah satu kebijakannya yang sensasional adalah penutupan lokalisasi Dolly, sebagai area pelacuran terbesar di Asia Tenggara, menambah popularitasnya semakin tinggi.

Sementara itu, Azwar Anas selama menjadi bupati di wilayah paling timur di propinsi Jawa Timur itu mampu mempopulerkan daerahnya melalui programprogram inovatifnya. Kini banyuwangi menjadi tujuan pariwisata terpopuler selain Batu Malang dan Gunung Bromo di Jawa Timur. Semua itu berkat kegigihan Azwar membangun dunia pariwisata daerahnya. Klimaksnya ketika kabupaten yang berjuluk "The Sunrise of Java" ini, berhasil meraih penghargaan dari Badan Pariwisata Perserikatan Bangsa-Bangsa (The United Nations World Tourism Organization/UNWTO) dalam ajang "12th UNWTO Awards Forum" di Madrid, Spanyol. Kabupaten Banyuwangi menyabet UNWTO Awards for Excellence and Innovation in Tourism untuk kategori "Inovasi Kebijakan Publik dan Tata Kelola" dengan mengalahkan nominator lainnya dari Kolombia, Kenya, dan Puerto Rico.Tentu ini menambah kekuatan petahana di Banyuwangi untuk meyakinkan pemilihnya untuk memberikan eluang kedua kali memimpin daerahnya. 
Kebijakan publik yang dilakukan petahana selama menjabat, menjadi salah satu ukuran yang menentukan kemenangannya dalam pilkada. Sebagaimana konsep responsivitas menyatakan bahwa kebijakan yang responsif adalah kebijakan yang dibuat sebagai respons terhadap aspirasi atau kebutuhan dasar masyarakat (pro poor policy), maka petahana yang sukses mendulang kemenangan pilkada, seperti yang diraih Risma dan Azwar, adalah tidak lain karena nilai responsivitas sebagai wujud amalan filsafat "untuk rakyat" memang dirasakan masyarakat langsung. Amat lumrah jika petahana yang demikian mampu meraih kemenangan mutlak dalam pilkada. Sebaliknya, jika responsivitas jauh dari harapan masyarakat, maka "hukuman" (stick) akan diberikan dalam bentuk kekalahan yang telak sekalipun.

Kisah Bupati petahana Bengkalis, Herlyan Saleh kalah telak dalam pemilihan kepala daerah serentak 2015 Bengkalis adalah salah satunya. Herlyan yang berpasangan dengan Riza Pahlevi justru menduduki posisi paling buncit dari dua pasangan calon bupati lainnya. Menuut Koordinator Forum Indonesia untuk Transparansi Anggaran (Fitra) Riau Usman menyebutkan, status tersangka korupsi yang disandang Herlyan Saleh sangat mempengaruhi merosotnya suara bupati inkumben itu. Selain itu ketidakpercayaan masyarakat juga tampak dari 5 tahun masa kepemimpinan Herlyan Saleh tidak memberikan dampak signifikan terhadap pembangunan infrastruktur dan ekonomi. Padahal Bengkalis merupakan daerah terkaya di Riau yang memiliki APBD mencapai Rp. 5 triliun. Namun program pembangunan infrastruktur dan ekonomi tidak menyentuh kalangan masyarakat bawah. Belum lagi petani karet yang sudah lima tahun lamanya terpuruk lantaran harga murah. Masih banyak desa yang tidak dialiri listrik di Rupat, begitu pula akses jalan yang tidak beraspal di desa-desa. ${ }^{103}$

$$
\text { Jauh sebelum pilkada } 2015
$$

diselenggarakan, Heru Kundhimiarso menjelaskan bahwa hal-hal yang menyebabkan petahana mengalami kekalahan adalah sebagai berikut: Pertama, Tingkat popularitas calon petahana ternyata tidak berbanding lurus dengan tingkat ke disukainya dan keterpilihannya (elektabilitasnya) di mata rakyat. Hal ini bisa diakibatkan melekatnya persepsi negatif dalam diri sang petahana, baik dari sisi moralitas, karakter pribadi, maupun gaya kepemimpinannya. Tingkat ketidaksukaan rakyat terhadap karakter personal dan gaya kepemimpinan seorang petahana akan membentuk politik persepsi yang sedemikian kuat di mata publik, seperti kesan arogan, sok pintar, sok kuasa, pemarah, berjarak dengan rakyat dll.

Kedua, Kekalahan petahana tersebut bisa dibaca sebagai bentuk protes langsung rakyat atas kepemimpinan sang petahana atau

103 Tempo, "Ini Penyebab Kekalahan Bupati Petahana Bengkalis Riau", dalam https://m.tempo.co/read/news /2015/12/18/058728852/ini-penyebab-kekalahan-bupatipetahana-bengkalis-riau. Diunduh [ada 5 Mei 2016. 
pejabat politik di daerah tersebut. Petahana dianggap mengingkari janji-janji kampanye pada saat pertama maju mencalonkan diri. Petahana dinilai gagal mewujudkan kesejahteraan, gagal dalam menjalankan kepemimpinannya. Sehingga rakyat yang tidak puas melampiaskan ketidakpuasannya tersebut dengan cara menghukum sang petahana dengan tidak memilihnya kembali.

Ketiga, Masyarakat memiliki keinginan kuat untuk melakukan perubahan dan mereka melakukan gerakan penolakan terhadap status quo yang dibangun petahana, hal ini terjadi karena masyarakat telah melihat kepemimpinan petahana yang tidak mampu dan tidak berhasil melakukan perubahan dalam masa kepemimpinannya. Semangat perubahan yang diinginkan masyarakat, akan membangun persepsi politik yang seolah-olah vis a vis antara pro status quo dengan pro perubahan.

Keempat, Kondisi masyarakat saat ini yang mulai otonom dan rasional dalam menentukan pilihannya, masyarakat tidak lagi tergantung pada bendera parpol yang mengusung calon, masyarakat tak mau lagi terbuai dengan money politik yang diberikan oleh sang kandidat. Masyarakat kini lebih melihat berdasarkan pada visi, misi, dan program kerja konkret yang ditawarkan calon. Lebih tertarik dengan sosok figur calon yang mencerminkan kesederhanaan, dekat dengan rakyat, jujur, ramah, dan low profile. Pilkada
DKI Jakarta contoh paling dekat dan paling tepat dengan sosok Jokowi nya. ${ }^{104}$

Maka menjadi hal yang lumrah jika petahana gagal dalam pilkada tidak lain dikarenakan faktor-faktor tersebut. Tingkat melek politik masyarakat sejak masa reformasi ini memang meningkat pesat. Tidak saja apatisme dalam bentuk golput disuarakan dalam pilkada tetapi juga "hukuman" untuk petahana yang tidak responsif terhadap kesejahteraan masyarakat menjadi taruhan yang penting.

\section{Kesimpulan}

Proses pilkada di Indonesia sejak reformasi menandakan era baru, ketika masyarakat menjadi aktor penting dalam proses pemilihan. Berbeda dengan masa Orde Baru dimana mayoritas masyarakat mengikuti pemilihan umum di level nasional, karena di level daerah semua kepala daerah ditunjuk oleh Soeharto, adalah berdasarkan mobilitas pusat, sehingga amat wajar jika tingkat partisipasinya rata-rata diatas 85 persen. Namun begitu partisipasinya dianggap semu, karena tidak disertai dengan keterwakilan, transparansi dan akuntabilitas, apatah lagi responsivitas yang memadai. Di masa reformasi partisipasi aktif masyarakat dalam pilkada disertai dengan pemantauan sepanjang periode pemimpin daerah ketika menjabat,

\footnotetext{
104 Puskapik, "Musim Bergugurannya Calon Incumbent (Petahana) dalam Pilkada, bagaimana dengan Pemalang ?" dalam http://www.puskapik.com/musimbergugurannya-calon-petahana-incumbent-dalampilkada-bagaimana-dengan-pemalang/. Diunduh pada 5 Mei 2016.
} 
sehingga amatlah wajar unsur responsivitas menjadi variabel penting dalam proses berdemokrasi secara menyeluruh.

Partisipasi yang aktif secara ideal memang harus disertai dengan responsivitas yang tinggi. Kepercayaan politik yang diberikan pemilih dalam pilkada agar penyelenggara negara menjalankan kebijakankebijakan yang responsif terhadap kebutuhan masyarakat, dewasa ini semakin mengemuka. Kemenangan dan kekalahan petahana dalam pilkada dapat dinyatakan bahwa keterkaitan partisipasi dan responsivitas menjadi amat penting dalam proses demokrasi lokal secara menyeluruh.

\section{Daftar Pustaka}

Badan Pengawas Pemilihan Umum Republik Indonesia, "Pilkada Semakin Demokratis Tapi Partisipasi Cenderung Menurun", Selasa, 10 November 2015, dalam http://bawaslu.go.id/id/berita/pilkadasemakin-demokratis-tapi-partisipasicenderung-menurun. Diunduh pada 1 Mei 2016.

BBC Indonesia, "Pilkada serentak, sejumlah calon petahana unggul", dalam http://www.bbc.com/indonesia/berita_ indonesia/2015/12/151210_indonesia _pilkada_petahana. Diunduh pada 1 Mei 2016.

Camille Burnet, Henry Minis, dan Jerry VanSant, Democratic Decentralization, dalam
http://www.rti.org/pubs/Democr_Dec en.PDF. Diakses 10 Januari 2008.

Dedy Priatmojo, "Lima Faktor Calon Petahana Unggul di Pilkada Serentak", dalam http://politik.news.viva.co.id/news/rea d/709835-lima-faktor-calonpetahana-unggul-di-pilkada-serentak. Diunduh pada 5 Mei 2016.

De Tocqueville, A. (2003). Democracy in america (Vol. 10). Regnery Publishing.

Diamond, L. (1999). Developing democracy: Toward consolidation. JHU Press. Dwiyanto, A. (2006). Reformasi birokrasi publik di Indonesia. Gadjah Mada University Press.

Easton, D. (1957). An approach to the analysis of political systems. World politics, 9(03), 383-400.

Fatkhurohman, F. (2010). Pilkada Dan Masa Depan Penguatan Demokrasi di Daerah. Jurnal Konstitusi, 3(2).

Fitriyah, F. (2013). Meninjau Ulang Sistem Pilkada Langsung: Masukan Untuk Pilkada Langsung Berkualitas.

Frerks, G. E., Otto, J. M., \& Asmerom, H. K. (1996). Decentralization and Development: A Review of Development Administration Literature: In Commemoration of $\mathrm{Dr}$ Haile K. Asmerom. Van Vollenhoven Institute for Law and Administration in Non-Western Countries. 
Hijri, Y. S. (2016). KPUD, Pilkada Langsung dan Demokrasi Lokal. Jurnal Bestari, 1(37).

Kompas, "Petahana Tetap Kuat di Pilkada 2015", dalam http://nasional.kompas .com/read/2016/01/07/02205431/Peta hana.Tetap.Kuat.di.Pilkada.2015. Di unduh pada 5 Mei 2016.

MacAndrews, C., \& Mas'ud, M. (1991). Perbandingan Sistem Politik. Gadjah Mada University Press.

Manor, J., \& World Bank. (1999). The political economy of democratic decentralization.

Pratikno (2005). "Demokrasi dalam Pilkada Langsung", Makalah, Sarasehan Menyongsong Pilkada Langsung, IRCOS-FNSt, Hotel Saphir, Yogyakarta, 25-26 Januari 2005.

Puskapik, "Musim Bergugurannya Calon Incumbent (Petahana) dalam Pilkada, bagaimana dengan Pemalang?" dalam http://www.puskapik.com/ musimbergugurannya-calon-petahanaincumbent-dalam-pilkadabagaimana-dengan-pemalang/. Diunduh pada 5 Mei 2016.

Putnam, R. D., Leonardi, R., \& Nanetti, R. Y. (1994). Making democracy work: Civic traditions in modern Italy. Princeton university press.

Rondinelli, DA. (1998). "What is Decentralization?" Note prepared for the PREM Knowledge Management
System, World Bank, Washington, DC.

Rumesten, I. (2014). Korelasi Perilaku Korupsi Kepala Daerah dengan Pilkada Langsung. Jurnal Dinamika Hukum, 14(2).

Saraswati, R. (2014). Reorientasi Hukum Pemilukada yang Mensejahterakan Rakyatnya. Jurnal Dinamika Hukum, 14(2).

Simamora, J. (2011). Eksistensi Pemilukada Dalam Rangka Mewujudkan Pemerintahan Daerah yang Demokratis. Mimbar Hukum-Fakultas Hukum Universitas Gadjah Mada, 23(1), 221-236.

Siri Gloppen, Lise Rakner and Arne Tostensen, Responsiveness to the Concerns of the Poor and Accountability to the Commitment to Poverty Reduction, dalam http://www.undp.org/oslocentre/PAR _Bergen_2002/concerns-poor-issuespaper.pdf. (20 Januari 2015).

Sisk, T. D., Ballington, J., Subiyanto, A., \& Maxim, S. (2002). Demokrasi di tingkat lokal: buku panduan International IDEA mengenai keterlibatan, keterwakilan, pengelolaan konflik, dan kepemerintahan. International IDEA.

Smith, B. C., \& Smith, B. C. (1985). Decentralization: the territorial dimension of the state (pp. 1-52). London: Allen \& Unwin. 
Soebagio, H. (2008). Implikasi Golongan Putih Dalam Perspektif Pembangunan Demokrasi di Indonesia. Sumber, 21(8).

Sutoro, E. (2006). Voice, Akses, dan Kawalan Masyarakat, makalah dalam www.ireyogya.org/sutoro/voice_dan_ akses_masyarakat.pdf. $\quad(2$ Pebruari 2006)

Suyatno (2011). Dinamika Demokrasi Tempatan di Indonesia: Kajian Demokrasi Tempatan di Kota Yogyakarta dan Kabupaten Jembrana, Bali, Tesis PhD Universiti Sains Malaysa.

Tempo, "Ini Penyebab Kekalahan Bupati Petahana Bengkalis Riau", dalam https://m.tempo.co/read/news/2015/12 /18/058728852/ini-penyebabkekalahan-bupati-petahanabengkalis-riau. Diunduh pada 5 Mei 2016. 